\title{
EXPLOITATION OF RAPE FLOW BY BEE COLONIES IN STATIONARY AND MIGRATORY APIARY
}

\author{
Dariusz Teper*, Piotr Skubida, \\ Piotr Semkiw, Wojciech Skowronek \\ Research Institute of Horticulture, Apiculture Division \\ Kazimierska 2, 24 - 100 Puławy \\ *corresponding author: dariusz.teper@man.pulawy.pl
}

Received 29 January 2013; accepted 29 March 2013

$\mathrm{S}$ u m m a r y

The aim of the study conducted in 2009 - 2011 was to estimate the differences in the nectar and pollen oilseed rape flow exploitation by bee colonies kept in the stationary apiary (permanently located on the rape field) and in the migratory apiary. The migratory apiary was transferred to the rape field at the appropriate time and situated on the same area as the stationary apiary. Every study year, 8 bee colonies per apiary, in two apiaries of different types (stationary and migratory apiary), were prepared. The colonies from the migratory apiary were placed on the rape field when about $10 \%$ of rape flowers were blooming. During that time, bottom pollen traps were inserted into the hives of both apiaries. The pollen loads were collected every day, separately from each colony. After the end of the flow season, honey was extracted separately from each colony. The honey was weighed and samples were taken for the palynological analysis. The weather conditions were monitored during the whole study period.

The average harvest of pollen loads from one bee colony during one day, was similar in both apiaries. The content of Brassica napus pollen was significantly higher in the pollen loads harvested from the migratory apiary. Despite the fact that the amounts of honey extracted from both apiaries were similar, the microscopic pollen analysis showed significantly higher percentage content of rape pollen in the honey from the migratory apiary. The results confirmed that placing the migratory apiary in the winter rape field at the time when about $10 \%$ of flowers were blooming resulted in a better exploitation of the rape flow by the bee colonies from this apiary in comparison to the colonies from the stationary apiary.

Keywords: stationary apiary, migratory apiary, winter rape, Brassica napus var. oleifera, pollen loads, honey, pollen analysis.

\section{INTRODUCTION}

Winter rape is one of the most important main nectar sources in Poland. Sugar yield from 1 ha of crops reaches $120 \mathrm{~kg}$. While the pollen yield can be even higher, up to $160 \mathrm{~kg} / \mathrm{ha}$ (Kołtowski, 2002).

Beside the honey production, obtaining the pollen loads significantly improves the economical results of apiaries (Pidek, 1988, Cichoń and Wilde, 2002). In Poland, the increase in the amount of the obtained pollen loads to over $2 \mathrm{~kg} /$ colony, significantly decreases the amount of the extracted honey
(Bratkowski and Wilde, 2002). However, a new study suggested that commercial selection for high pollen yield, which makes the high pollen harvest possible, should not affect honey yield (Wilde et al., 2011). Other studies have shown that pollen loads production is less influenced by the course of weather conditions than by the honey production (Wilde et al., 2002). In the regions with poor early spring flows of Salix, Acer or Taraxacum officinalis, pollen collection needs to be started at the beginning of the winter rape flowering period (Wilde et al., 1994). What is more, these studies had 
shown that the biggest amounts of pollen loads were obtained when the pollen load traps were inserted into the hives directly after placing the colonies on the flowering winter rape field.

In Poland, the flowering period of winter rape falls on the beginning of May. Therefore the period between the end of the bees' wintering (usually at the turn of March and April) and the occurrence of winter rape flow is too short to allow optimal preparation of bee colonies to the flow exploitation. That is why it is crucial to take measures of improving spring colony development during that time (Skubida et al., 2008), and at the later stage, proper management of the colonies structure needs to be conducted. Beside the abovementioned conditions, the exploitation of the flow is also influenced by the distance between the apiary and the flow source (Wilde, 2008). This was supported by the fact that when bees were transported to the vicinity of the winter rape field from the relatively close distance of $1 \mathrm{~km}$, the amount of obtained honey increased, on the average, by $175 \%$. In bad weather conditions the amount of obtained honey increased even by nearly 300\% (Bobrzecki, 1973).

In the beekeepers opinion, for good exploitation of honey flow and for obtaining pure unifloral honeys, bee colonies should be transported to the honey flow field when 10 to $30 \%$ of flowers bloom. This way scout bees exploring the apiary's surroundings can then pass on the information that in the vicinity an intensive and plenteous source of flow is present. Thanks to that, great majority of foragers can then concentrate on the exploitation of this particular flow. The literature data concerning this issue are very poor. Only Jabłoński (1998) indicated the necessity of transporting the bee colonies to the crops of interest to beekeepers at the appropriate time, i.e. at the beginning of the plants' flowering period, when about $10 \%$ of flowers bloom. Bees placed on the field at an earlier time, when penetrating the area, can find a different source of nectar flow (e.g. orchards, dandelion), especially when the weather is good. Bees will use the new source as long as it will supply them with the flow, omitting the plants that bloomed later (e.g. winter rape).

The aim of the study was to evaluate the differences between the exploitation of the nectar and pollen rape flow by the bee colonies in the stationary apiary (permanently located on the rape field) and in the migratory apiary - placed on the field at the right time, i.e. when about $10 \%$ of rape flowers bloomed.

\section{MATERIAL AND METHODS}

The studies were conducted in the Research Institute of Horticulture, Apicultural Division in Puławy, Poland, in 2009-2011 on the several-hectare field of winter rape cultivated in the Agricultural Experimental Unit in Puławy - Kępa of the Institute of Soil Science and Plant Cultivation in Puławy, Poland.

For the experiment, 8 colonies of Apis mellifera caucasica honeybees per apiary, in two types of apiaries, were prepared. Colonies of similar strength, set in the Wielkopolski hives (frame size $360 \times 260 \mathrm{~mm}$ ), had sister queens in the F1 generation and had no clinical symptoms of any diseases. First apiary - stationary, was permanently situated in Puławy in a vicinity of the winter rape field. While the migratory apiary was localized in Nasiłów at a distance of about $10 \mathrm{~km}$ from the experimental rape field.

Every year before the experiment brood area was measured two times. At the same time the colonies' strength was estimated (number of combs covered by bees). First measurements were taken during the first routine inspections (2009 - 1 April, 2010 - 13 April, 2011 - 12 April); the second ones were taken 21 days later (2009 22 April, 2010 - 4 May, and 2011 - 6 May). During the inspections, when necessary, new frames with light colored combs or with comb foundation were inserted into the colonies. To optimally prepare the colonies for exploitation of the rape flow, the management procedures for equalizing 
the colonies' strengths (rotation of brood combs) were conducted and the combs with supplies were detached. This stimulated the spring development of colonies.

Bee colonies from the migratory apiary were transferred to the field at the time when about $10 \%$ of rape flowers were blooming: in 2009 - 27 April, in 2010 - 4 May, and in 2011- 5 May. The migratory apiary was situated in the same area as the stationary apiary. At that time, the bottom pollen traps were inserted into the hives. The first collections of pollen were carried out 3 days after inserting the pollen traps. After that, pollen loads were collected every day in the afternoon (between 14.00 and 15.00). Periods of pollen loads collections in each of the study years were related with the rape flowering duration. In 2009 lasted from 30 April to 22 May (23 days); in 2010 - from 7 May to 23 May (17 days); and in 2011 - from 8 May to 24 May (17 days). The pollen loads collected from each colony were poured from the traps' drawers into plastic bags marked with the collection date, apiary type, and colony's number, and weighed. From every portion of pollen loads samples were taken to prepare microscopic sections for the palynological analysis. The rest of pollen loads was frozen.

When the rape flow ended, honey was extracted separately from every colony. The honey was weighed and samples were taken for the palynological analysis. Extraction of honey was carried out on the following dates: 2009 - 24 May, 2010 25 May, 2011 - 27 May. The honey was taken only from combs located in the upper hive body, above the queen excluder.

During the study atmospheric conditions were monitored. Air temperature and humidity were measured every two hours from 10.00 to 18.00 , and the readings of total precipitation were taken daily at 8.00.

Botanical origin of the honey and pollen samples was determined using the palynological analysis. Analyses of pollen loads and honey were performed separately for each colony and separately for the extraction date. The total number of pollen loads samples from the stationary apiary were 456 . The same number of samples were taken from the migratory apiary. Total number of honey samples from the stationary and migratory apiaries were the same, 24.

Before conducting the analysis, each sample of pollen loads was thoroughly mixed. Then, samples of about $20 \mathrm{~g}$ were put into screw-capped plastic containers and next about $20 \mathrm{ml}$ of distilled water were added. The containers were capped and left for several hours for the pollen loads to soften. To speed up the softening, containers were intensively shaken from time to time. After obtaining a homogeneous suspension, a small portion was transferred with a pipette on a labeled microscope slides doing regular smears. The slides with smears were then left for few minutes to dry. The dried smears with a drop of glycerol-water solution (1:1) were covered with a cover slip. Pollen analyses of the collected material were performed using the biological microscope Olympus BX41 under magnification 400x. In each microscopic slide, in successive view fields of the microscope, all the pollen grains of each plant species were counted separately, until the total number of 300 grains was exceeded. The results were recorded in a table of the MS Excel spreadsheet file. The percentage content of every pollen type was calculated.

Pollen analysis of honey was performed according to themethodology recommended by the International Commission of Bee Botany and International Honey Commission (Louveaux et al., 1978).

The results were statistically analysed using STATISTICA 10 software. The two-way ANOVA was used for statistical calculations. Duncan's multiple range test was applied to determine significant differences between the means. For all analyses, p-value $<0.05$ was considered significant. 


\section{RESULTS}

Despite the fact that the apiaries were situated in distant locations, all bee colonies had similar flow conditions (Salix spp., Acer spp., and various Prunus spp.) from early spring, so their spring development was similar. No significant differences in the measured parameters (brood area and the number of combs covered by bees) were found between groups (Tab. 1).

The weather conditions, particularly temperature during the winter rape flowering period, had the highest influence on the amount of collected pollen loads, irrespective of the apiary type (Fig. 1). The average mass of pollen loads collected by one colony during one day in both apiaries was similar (Tab. 2). The lowest amounts of pollen were collected by bee colonies in 2009 . In the stationary apiary, the average mass of pollen loads collected daily by one colony was $30.7 \mathrm{~g}$, while in the migratory apiary $33.3 \mathrm{~g}$. In 2010, these amounts were higher in comparison to the previous year. The best results were observed in 2011 when in both apiaries the average amounts of pollen loads collected daily by one colony were similar and amounted to over $100 \mathrm{~g}$ (Tab. 2).

In 2009, pollen loads were collected for 22 days. The average mass of pollen collected per one colony during that time in the stationary apiary, amounted to $706.6 \mathrm{~g}$ while in the migratory apiary $765.6 \mathrm{~g}$. In 2010 , the period of pollen collection was shorter, only 17 days. Despite that, the average pollen production in the apiaries was higher. In the stationary apiary, one colony collected $850.2 \mathrm{~g}$ of pollen loads and in the migratory apiary one colony collected $907.9 \mathrm{~g}$ of pollen loads. 2011 was the record year for the pollen collection. The collection period also lasted for 17 days but during that time one colony of the stationary apiary provided, on average, $1862.6 \mathrm{~g}$ of pollen loads, and the average for the migratory apiary was $1765.4 \mathrm{~g}$ of pollen loads per colony. These high results of 2011, resulted in the following amounts of the average mass of pollen loads collected during the whole study period: the stationary apiary $1139.8 \mathrm{~g}$ of pollen loads per one colony, and the migratory apiary $1146.4 \mathrm{~g}$ of pollen loads per one colony.

Microscopic analysis was done of the pollen load samples collected during the three years of the experiment. The analysis of the combined data from all 3 study years showed that the average percentage content of Brassica napus pollen was significantly higher in the pollen loads from the migratory apiary and amounted to $29.4 \%$, while in the stationary apiary

Table 1 .

Biological state of bee colonies from the stationary and migratory apiary before the winter rape flowering period

\begin{tabular}{|c|c|c|c|c|c|c|c|c|c|}
\hline \multirow{3}{*}{ Year } & \multirow{3}{*}{$\begin{array}{l}\text { Group } \\
(\mathrm{n})\end{array}$} & \multicolumn{4}{|c|}{$\begin{array}{c}\begin{array}{c}\text { Brood area } \\
\left(\mathrm{dm}^{2}\right)\end{array} \\
\end{array}$} & \multicolumn{4}{|c|}{$\begin{array}{l}\text { Number of combs } \\
\text { covered by bees }\end{array}$} \\
\hline & & \multicolumn{2}{|c|}{ Measurement I } & \multicolumn{2}{|c|}{ Measurement II } & \multicolumn{2}{|c|}{ Measurement I } & \multicolumn{2}{|c|}{ Measurement II } \\
\hline & & Average & SD & Average & $\mathrm{SD}$ & Average & SD & Average & $\mathrm{SD}$ \\
\hline \multirow{3}{*}{2009} & $\mathbf{M}^{\star}(8)$ & 9.1 & 2.0 & 45.2 & 10.0 & 7.6 & 1.2 & 13.6 & 2.6 \\
\hline & $\mathbf{S}^{*}(8)$ & 9.9 & 4.1 & 47.0 & 10.7 & 7.1 & 1.1 & 13.1 & 1.1 \\
\hline & $p$-value** & \multicolumn{2}{|c|}{0.76} & \multicolumn{2}{|c|}{0.76} & \multicolumn{2}{|c|}{0.31} & \multicolumn{2}{|c|}{0.55} \\
\hline \multirow{3}{*}{2010} & $\mathbf{M}^{*}(8)$ & 37.6 & 10.4 & 57.8 & 13.5 & 8.6 & 0.7 & 15.2 & 0.7 \\
\hline & $\mathbf{S}^{*}(8)$ & 32.9 & 4.1 & 55.3 & 8.3 & 8.7 & 0.7 & 15.0 & 2.0 \\
\hline & $p$-value ${ }^{\star \star}$ & \multicolumn{2}{|c|}{0.13} & \multicolumn{2}{|c|}{0.68} & \multicolumn{2}{|c|}{0.78} & \multicolumn{2}{|c|}{0.76} \\
\hline \multirow{3}{*}{2011} & $\mathbf{M}^{\star}(8)$ & 23.7 & 6.0 & 62.4 & 11.4 & 7.4 & 0.7 & 17.0 & 0.7 \\
\hline & $\mathbf{S}^{*}(8)$ & 24.9 & 7.4 & 65.0 & 16.7 & 7.2 & 0.7 & 17.0 & 2.0 \\
\hline & $p$-value ${ }^{\star *}$ & \multicolumn{2}{|c|}{0.69} & \multicolumn{2}{|c|}{0.66} & \multicolumn{2}{|c|}{0.78} & \multicolumn{2}{|c|}{1.0} \\
\hline
\end{tabular}

* M - migratory apiary, S - stationary apiary

** ANOVA test, $\mathrm{p}<0.05$ 
Type of apiary ${ }^{*}$ year of study; LS Means

Current effect: $F_{(2,108)}=0.13285, p=0.87574$

Effective hypothesis decomposition

Vertical bars denote 0.95 confidence intervals

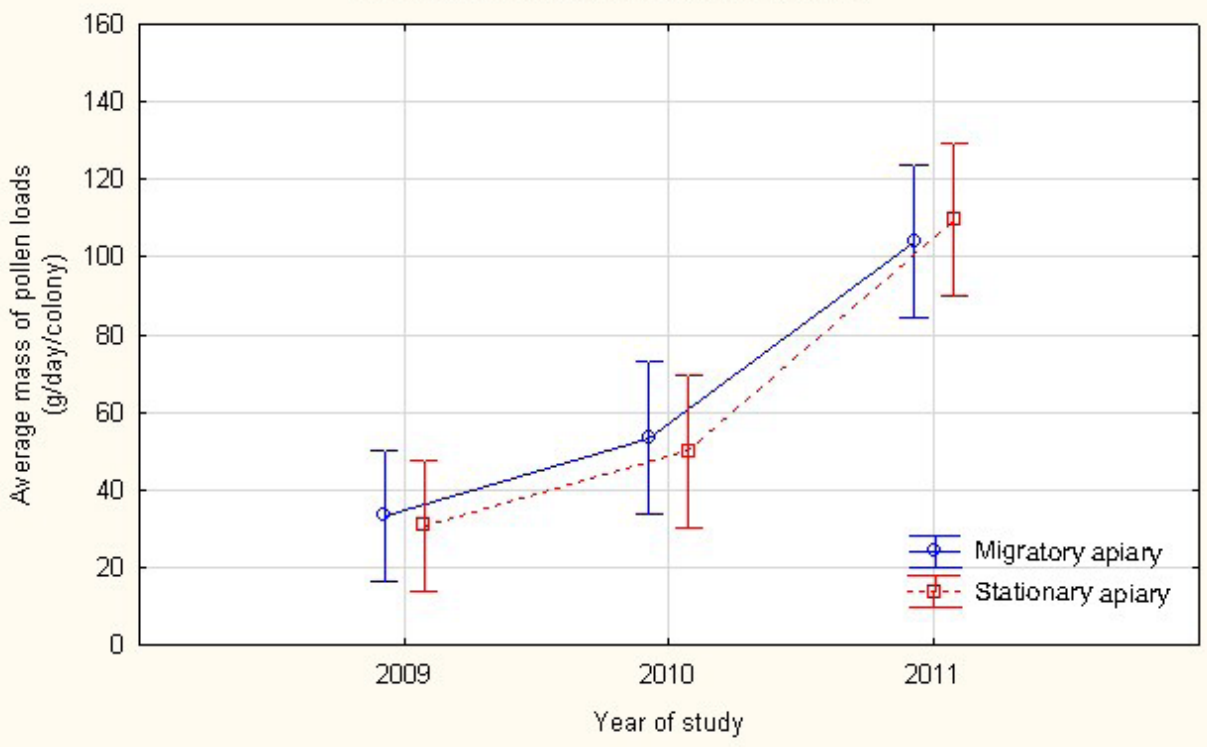

Fig. 1. Interaction between the type of apiary, year of the research and the average mass of pollen loads ( $\mathrm{g} /$ day/colony).

Table 2 .

Comparison of the analysed parameters between the stationary and migratory apiary in the individual study years

\begin{tabular}{|c|c|c|c|c|c|c|c|c|c|c|c|c|}
\hline \multirow{2}{*}{$\begin{array}{c}\text { Analysed } \\
\text { parameter }\end{array}$} & \multirow{2}{*}{ Group } & \multicolumn{3}{|c|}{2009} & \multicolumn{3}{|c|}{2010} & \multicolumn{3}{|c|}{2011} & \multicolumn{2}{|c|}{ Total } \\
\hline & & $\mathrm{n}$ & Average & SD & $n$ & Average & SD & $\mathrm{n}$ & Average & SD & Average & SD \\
\hline \multirow{3}{*}{$\begin{array}{c}\text { Mass of } \\
\text { pollen loads } \\
\text { (g/day/colony) }\end{array}$} & $\mathbf{M}^{*}$ & 184 & 33.3 & 13.9 & 136 & 53.4 & 28.5 & 136 & 103.8 & 65.0 & 60.3 & 49.0 \\
\hline & $\mathbf{S}^{*}$ & 184 & 30.7 & 15.2 & 136 & 50.0 & 28.8 & 136 & 109.5 & 69.8 & 59.9 & 53.4 \\
\hline & $p$-value ${ }^{\star *}$ & \multicolumn{3}{|c|}{0.84} & \multicolumn{3}{|c|}{0.80} & \multicolumn{3}{|c|}{0.67} & \multicolumn{2}{|c|}{0.96} \\
\hline \multirow{3}{*}{$\begin{array}{c}\% \text { of rape } \\
\text { pollen in } \\
\text { pollen loads }\end{array}$} & $\mathbf{M}^{*}$ & 184 & 38.8 & 13.0 & 136 & 22.3 & 13.0 & 136 & 23.9 & 12.2 & 29.4 & 14.8 \\
\hline & $\mathbf{S}^{*}$ & 184 & 28.3 & 9.2 & 136 & 23.7 & 13.9 & 136 & 12.6 & 11.4 & 22.3 & 13.0 \\
\hline & p-value ${ }^{\star \star}$ & \multicolumn{3}{|c|}{0.009} & \multicolumn{3}{|c|}{0.71} & \multicolumn{3}{|c|}{0.009} & \multicolumn{2}{|c|}{0.002} \\
\hline \multirow{3}{*}{$\begin{array}{l}\text { Honey } \\
\text { production } \\
\text { (kg/colony) }\end{array}$} & $\mathbf{M}^{*}$ & 8 & 5.6 & \begin{tabular}{|l|}
2.5 \\
\end{tabular} & 8 & 1.8 & 1.4 & 8 & 4.2 & 2.9 & 3.8 & 2.8 \\
\hline & $\mathbf{S}^{*}$ & 8 & 4.2 & 3.9 & 8 & 1.1 & 1.3 & 8 & 5.5 & 2.7 & 3.5 & 3.3 \\
\hline & $p$-value ${ }^{* *}$ & \multicolumn{3}{|c|}{0.33} & \multicolumn{3}{|c|}{0.60} & \multicolumn{3}{|c|}{0.43} & \multicolumn{2}{|c|}{0.70} \\
\hline \multirow{3}{*}{$\begin{array}{l}\% \text { of rape } \\
\text { pollen in } \\
\text { honey }\end{array}$} & $\mathbf{M}^{*}$ & 8 & 69.7 & 21.3 & 8 & 39.7 & 7.7 & 8 & 73.8 & 12.6 & 60.2 & 21.2 \\
\hline & $\mathbf{S}^{*}$ & 8 & 67.9 & 20.1 & 8 & 24.9 & 15.4 & 8 & 48.9 & 17.0 & 45.4 & 25.3 \\
\hline & p-value ${ }^{\star *}$ & \multicolumn{3}{|c|}{0.82} & \multicolumn{3}{|c|}{0.08} & \multicolumn{3}{|c|}{0.007} & \multicolumn{2}{|c|}{0.003} \\
\hline
\end{tabular}

* M - migratory apiary, S - stationary apiary

** ANOVA test, $\mathrm{p}<0.05$

Red colour indicates significant differences. 
$22.3 \%$ (Tab. 2). The same interrelation was shown in 2009 and in 2011. Only in 2010, when the content of $B$. napus pollen in the pollen loads from the migratory apiary was $22.3 \%$ and in the stationary apiary $23.7 \%$, the differences between groups were not statistically significant. The interaction between the study year and the apiary type did not influence the average percentage of $B$. napus pollen in pollen loads. Nonetheless, worse weather conditions in 2010 resulted in comparable exploitation of rapeseed pollen flow in both types of apiaries (Fig. 2).

During microscopic analysis in the collected pollen loads from stationary and migratory apiaries, apart from B. napus, pollen grains of other plants were found: Aesculus hippocastanum, Salix, Malus type, Prunus type, Taraxacum type, Acer, Quercus, Rubus type, Frangula, Juglans regia, Trifolium repens type, Pinus, Ranunculaceae, and others.

Assessment of honey productivity conducted every year, showed very low and similar honey productions in both apiaries (Tab. 2). The lowest average honey production per one colony was found in 2010 (below $2 \mathrm{~kg}$ ). In the remaining two years, the production of honey was running at a level of $5 \mathrm{~kg}$ per one bee colony. The three-year average amount of honey extracted from one bee colony in the stationary apiary was $3.5 \mathrm{~kg}$ and in the migratory apiary $3.8 \mathrm{~kg}$. There was no interaction between the year of the research, the type of apiary, and the honey production (Fig. 3).

The microscopic pollen analysis of the honey samples showed a significantly higher percentage content of Brassica napus in honey obtained from the colonies of the migratory apiary (Tab. 2). The threeyear average of the $B$. napus pollen content in the honey samples from the stationary apiary was $45.4 \%$ while from the migratory apiary $60.2 \%(45 \%$ - the lower limit of the Brassica napus pollen content in rape honey according to the Polish Standard PN-88/A-77626, 1998). In 2010 and

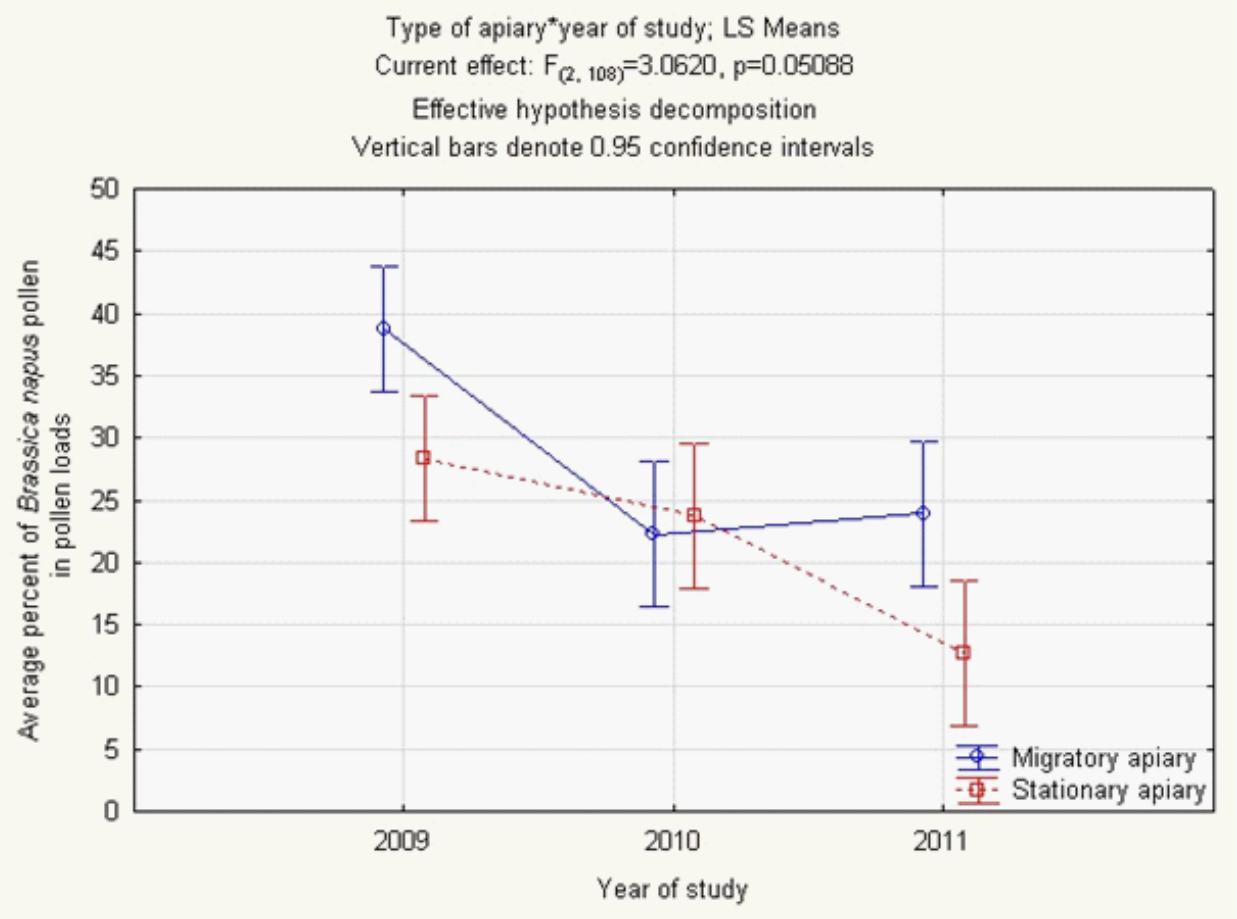

Fig. 2. Interaction between the type of apiary, year of the research, and the average percent of Brassica napus pollen in pollen loads. 
Type of apiary ${ }^{*}$ year of study; LS Means

Current effect: $F_{(2,44)}=1.1058, p=0.33998$

Effective hypothesis decomposition

Vertical bars denote 0.95 confidence intervals

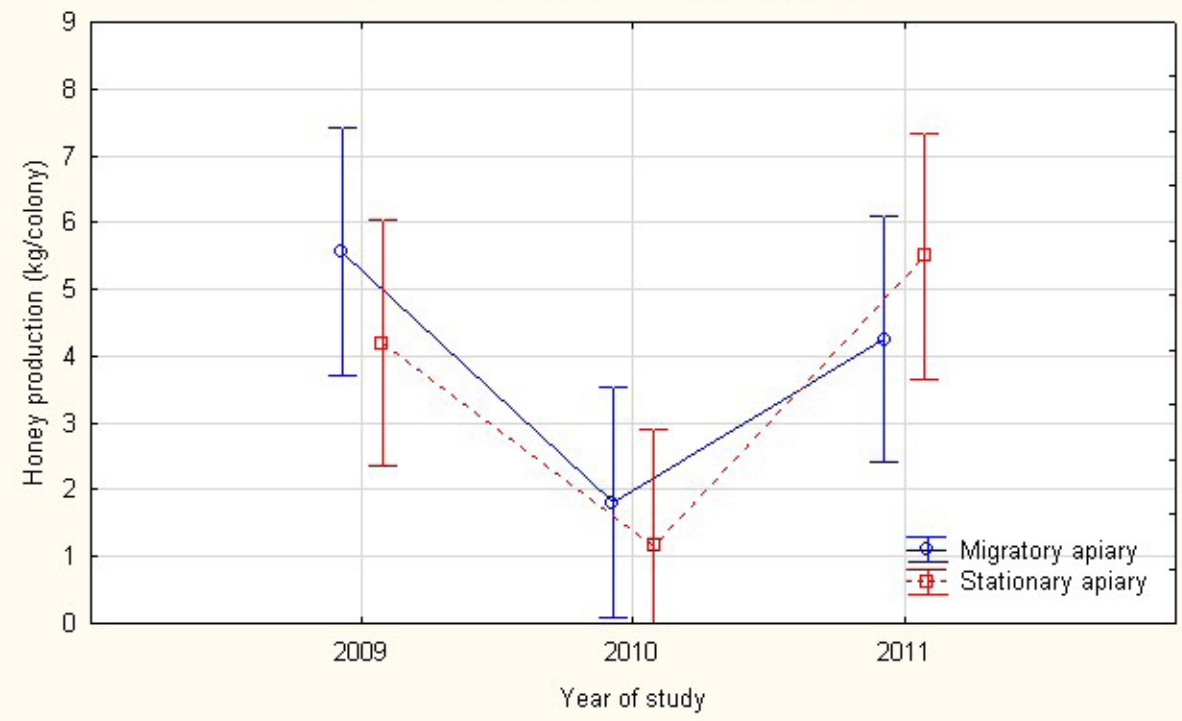

Fig. 3. Interaction between the type of apiary, year of the research, and the honey production ( $\mathrm{kg} /$ colony).

Type of apiary*year of study: LS Means

Current effect: $F_{(2,43)}=1.8354, p=0.17183$

Effective hypothesis decomposition

Vertical bars denote 0.95 confidence intervals

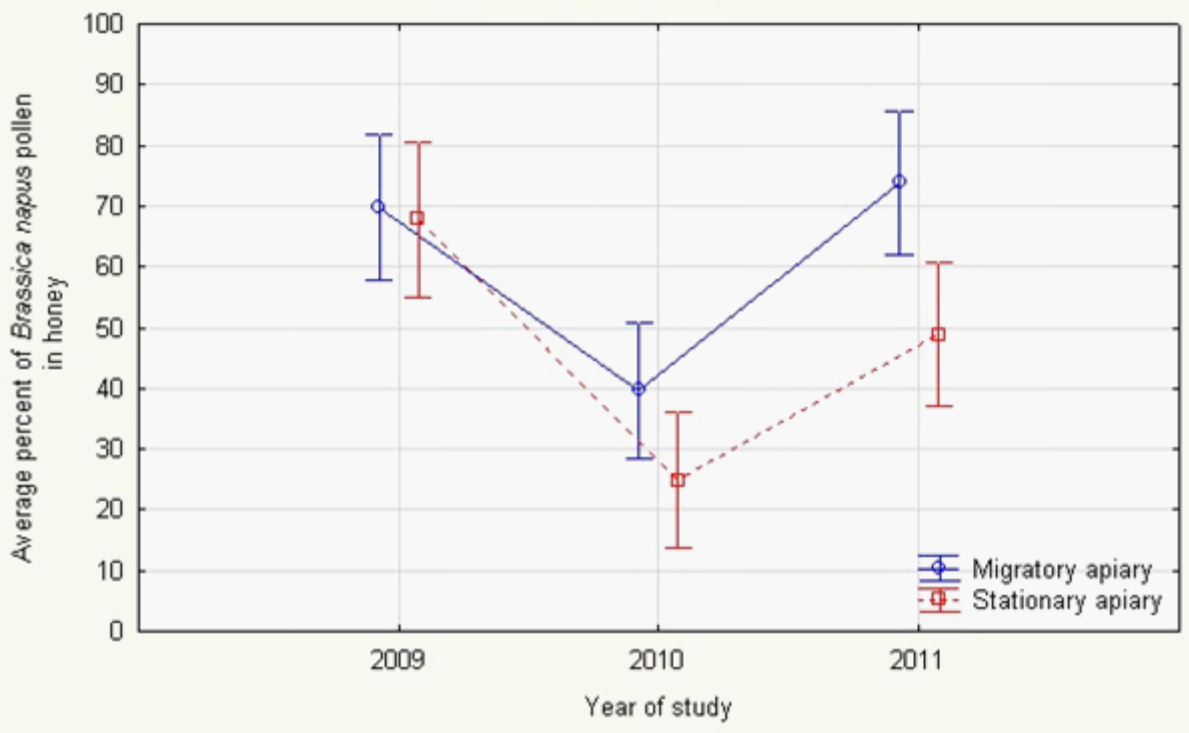

Fig. 4. Interaction between the type of apiary, year of the research, and average percent of Brassica napus pollen in honey. 
2011, statistically significant differences between apiaries were found. The honey samples from both apiaries did not differ significantly regarding the percentage content of B. napus pollen in 2009 only. The average contents of rape pollen in the honey samples from both groups were very similar: the stationary apiary $67.9 \%$, the migratory apiary $69.7 \%$. No influence of the interaction was found between the year of the research and type of apiary on the average percent of $B$. napus pollen in honey (Fig. 4).

\section{DISCUSSION}

The results obtained during the studies supported the reports of Jabłoński (1998). Placing the migratory apiary on the rape field at a time when about $10 \%$ of rape flowers were blooming resulted in better exploitation of the rape flow in comparison to the stationary apiary permanently placed on the rape field. Significantly higher percentage content of Brassica napus pollen in the pollen loads and honey from the migratory apiary was noted. This implies that bees from the migratory apiary exploited the flow better, but in case of bad weather conditions (like in 2010) exploitation of rapeseed pollen flow by bee colonies from a migratory apiary can be worse, when compared to a stationary apiary. On the basis of the obtained results, it can be assumed that where other honey flow exploitation is concerned, e. g. Robinia, Tilia, Fagopyrum or Calluna the interrelation would be similar. Undoubtedly, the results of the study should be implemented in the apiaries transported to the fields of entomophilous plants (e. g. orchards or berry shrubs) for proper pollination.

The collected data confirmed the previous observations of Wilde et al. (2002), that the production of pollen loads is less dependent on the weather conditions than the production of honey. During this experiment, the winter rape florescence usually occurred under conditions of lower temperatures and periodic rainfall. Despite that, the average mass of pollen loads collected by one bee colony amounted to
$1.1 \mathrm{~kg}$, while the average honey production in that time reached only from 3 to $4 \mathrm{~kg}$. Thus, as reported by Pidek (1988), obtaining the pollen loads resulted in a financial increase for the apiaries. According to the data reported by Bobrzecki (1973) and Wilde (2008), under the weather conditions in which the studies were conducted, better exploitation of the flow was presumably influenced by the short distance between the apiaries and the winter rape field.

\section{CONCLUSIONS}

1. The results supported the view that placing bee colonies on the honey flow field when at least $10 \%$ of the flowers are blooming, results in better exploitation of pollen flow and allows obtaining honey with a higher percentage of the main pollen thus increasing the chance of obtaining unifloral honey.

2. Transferring the migratory apiary to the rape field when about $10 \%$ of the flowers were blooming did not increase the total amount of pollen and honey collected by the bee colonies in comparison to the mass of pollen and honey collected by the colonies from the stationary apiary.

3. Bad weather conditions caused a worse exploitation of rapeseed pollen flow by bee colonies from the migratory apiary.

4. On the basis of the obtained results, it can be assumed that in a case of exploiting other flow plants e.g. Robinia, Tilia, Fagopyrum, Calluna, the interrelation would be similar.

\section{REFERENCES}

Bobrzecki J. (1973) - Intensywność powrotu pszczół przy przewożeniu rodzin pszczelich na małe odległości. [The rate of returning bees after short-distance transport of apiaries] Zesz. nauk. ART Olsztyn, 4: 235-247.

\footnotetext{
Bratkowski J., Wilde J. (2002) Technologie zwiększające pozyskiwanie obnóży pyłkowych w polepszaniu dochodowości pasiek. [Technologies allowing to obtain higher amounts of pollen loads and to improve the apiaries profitability] Biul. Nauk., 18(5): 113-122.
} 
Cichoń J. Wilde J. (2002) - Pollen trapping as a method of improving the profitability of apiary production. Biul. Nauk., 18(5): 144-150.

Jabłoński B. (1998) - Wiadomości z botaniki pszczelarskiej [News from the apiarian botany], in: Jarosław Prabucki (Ed.) Pszczelnictwo [Beekeeping], Wydawnictwo promocyjne „Albatros”, Szczecin, pp. 775-886.

Kołtowski Z. (2002) - Beekeeping value of recently cultivated winter rapeseed cultivars. J. Apic. Sci., 46(2): 23-33.

Louveaux J., Maurizio A., Vorwohl G. (1978) - International Commission for Bee Botany of IUBS. Methods of Melissopalynology. Bee World, 59: 139-157.

Pidek A. (1988) - Wpływ pozyskiwania pyłku na rozwój i produkcyjność rodzin pszczelich oraz efekty ekonomiczne pasiek. [Influence of pollen trapping on bee colony productivity and their economical effects] Pszczeln. Zesz. Nauk. 32: 197-213.

PN-88/A-77626 „Miód pszczeli” [Polish Standard "Honey"] - Dziennik Normalizacji i Miar nr 8, Wydawnictwa Normalizacyjne "Alfa"

Skubida P., Semkiw P., Pohorecka K. (2008) - Stimulative feeding of bees as one factor in preparing colonies for early nectar flows. J. Apic. Sci., 52(1): 65 - 72.
Wilde J., Krukowski R., Bobrzecki J. (1994) - Porównanie metod gospodarki pasiecznej umożliwiających zwiększenie ilości pozyskiwanych obnóży pyłkowych. [The comparison of the beekeeping technologies that allow to increase the amounts of obtained pollen loads] Acta Acad. Agricult. Techn. Olst. Zootechnica, 39: 181-191.

Wilde J., Cichoń J., Grabowski P. (2002) - Korzyści ukierunkowywania pasiek profesjonalnych na pozyskiwanie pyłku. [The benefits from adjusting the commercial apiaries to obtaining pollen loads] Biul. Nauk., 18: 9-17.

Wilde J. (2008) - Gospodarka pasieczna. [Beekeeping technology], in: Wilde J., Prabucki J. (Eds.) Hodowla Pszczół [Bees breeding], PWRiL, Oddział Poznań, pp. 203253.

Wilde J., Paleolog J., Grabowski P., Siuda M., Bratkowski J. (2011) Correlated and direct responses to selection for high and low pollen yield in a small, open population of Apis mellifera carnica. J. Apic. Res., 50(3): 181-189

\title{
WYKORZYSTANIE POŻYTKU RZEPAKOWEGO PRZEZ RODZINY PSZCZELE W PASIECE STACJONARNEJ I WĘDROWNEJ
}

\author{
Teper D., Skubida P., \\ Semkiw P., Skowronek W. \\ St r e s z c z e n i e
}

Celem badań prowadzonych w latach 2009 - 2011 było sprawdzenie różnic w wykorzystaniu nektarowego i pyłkowego pożytku rzepakowego przez rodziny pszczele z pasieki stacjonarnej (usytuowanej stale na tym terenie) i wędrownej - przywiezionej na pożytek w odpowiednim terminie i ustawionej na tym samym terenie co pasieka stacjonarna. W związku z tym w każdym roku trwania doświadczenia przygotowywano w dwóch typach pasiek (stacjonarnej i wędrownej) po 8 rodzin pszczelich. Rodziny pszczele z pasieki wędrownej przywożono na plantację w momencie zakwitnięcia ok. $10 \%$ kwiatów rzepaku. W tym czasie zakładano dennicowe poławiacze pyłku. Obnóża pyłkowe odbierano codziennie, oddzielnie z każdej rodziny pszczelej. Po zakończeniu 
pożytku odwirowywano miód oddzielnie z poszczególnych rodzin, ważono go i pobierano próbki potrzebne do wykonania analizy pyłkowej. W trakcie prowadzenia badań monitorowano warunki atmosferyczne.

Stwierdzono, że średnia masa obnóży pyłkowych zbieranych przez jedną rodzinę pszczelą w ciągu jednego dnia, w obu pasiekach, była zbliżona. Udział pyłku rzepaku był istotnie wyższy $\mathrm{w}$ obnóżach pochodzących $\mathrm{z}$ pasieki wędrownej. Mimo podobnych zbiorów miodu w obu pasiekach, mikroskopowa analiza pyłkowa wykazała istotnie wyższy procentowy udział pyłku rzepaku w miodzie pozyskanym z rodzin pszczelich z pasieki wędrownej. Wyniki jednoznacznie wskazują, że przywiezienie pasieki wędrownej na plantację rzepaku ozimego w czasie, gdy około $10 \%$ kwiatów było rozwiniętych, miało wpływ na lepsze wykorzystanie pożytku rzepakowego przez rodziny pszczele.

Słowa kluczowe: pasieka stacjonarna, pasieka wędrowna, rzepak ozimy, Brassica napus var. oleifera, obnóża pyłkowe, miód, analiza pyłkowa. 